\title{
The Involvement of Mitogen-Activated Protein Kinases in the

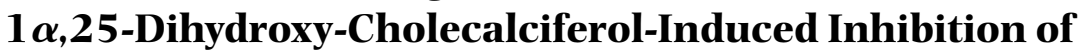 Adipocyte Differentiation In Vitro
}

\author{
Satoru SAKuma, Junji FujISAWA, Maki SumidA, Mami TANigaWA, Rie InODA, \\ Takuya SuJIHERA, Tetsuya KOHDA and Yohko FujIMOTO* \\ Laboratory of Physiological Chemistry, Osaka University of Pharmaceutical Sciences, 4-20-1 Nasahara, \\ Takatsuki, Osaka 569-1094, Japan
}

(Received August 22, 2011)

\begin{abstract}
Summary The present study was undertaken to investigate the mechanism by which $1 \alpha$, 25-dihydroxy-cholecalciferol $\left[1 \alpha, 25-(\mathrm{OH})_{2}-\mathrm{VD}_{3}\right]$ modulates the differentiation of mouse 3T3-L1 preadipocytes into mature adipocytes. Treatment with $1 \alpha, 25-(\mathrm{OH})_{2}-\mathrm{VD}_{3}$ in the presence of insulin, dexamethasone and 3-isobutyl-1-methyl-xanthine significantly inhibited the triacylglycerol accumulation, and mRNA expressions of adipocytokines (adiponectin and tumor necrosis factor- $\alpha$ ) and plasminogen activator inhibitor- 1 in the piconanomolar concentration range, indicating that $1 \alpha, 25-(\mathrm{OH})_{2}-\mathrm{VD}_{3}$ under physiological conditions inhibits the differentiation of 3T3-L1 cells. $1 \alpha, 25-(\mathrm{OH})_{2}-\mathrm{VD}_{3}$ potently reduced the mRNA and/or protein expressions of CCAAT-enhancer binding protein $\alpha(\mathrm{C} / \mathrm{EBP} \alpha)$ and peroxisome proliferator-activated receptor $\gamma(\operatorname{PPAR} \gamma)$, and the nuclear translocation of PPAR $\gamma$. Furthermore, it inhibited the mRNA expression and phosphorylation of extracellular signalregulated kinase (ERK), one of mitogen-activated protein kinases. These results indicate that $1 \alpha, 25-(\mathrm{OH})_{2}-\mathrm{VD}_{3}$ can be an inhibitor of adipocyte differentiation, and suggest, in addition to $\mathrm{C} / \mathrm{EBP} \alpha$ and PPAR $\gamma$, an important role of ERK in mediating $1 \alpha, 25-(\mathrm{OH})_{2}-\mathrm{VD}_{3}$-induced alteration in adipocyte differentiation.
\end{abstract}

Key Words 1 1 ,25-dihydroxy-cholecalciferol, adipocyte differentiation, 3T3-L1 cells, mitogen-activated protein kinases

Obesity is an important disease in the realm of preventive medicine because it is regarded as a risk factor for a broad spectrum of cardiometabolic disturbances, including dyslipidemia, hypertension, glucose intolerance, cardiovascular disease and type 2 diabetes mellitus $(1,2)$.

Adipocyte precursor cells (i.e., preadipocytes) are present throughout life. Accordingly, obesity may be partially mediated by stimulating the differentiation of preadipocytes into adipocytes or by increasing fat accumulation in the differentiated adipocytes (3). Furthermore, adipose tissue has recently been identified as an endocrine organ that secretes various kinds of bioactive molecules called adipocytokines $(4,5)$. The differentiation of preadipocytes into adipocytes is accompanied by many changes in gene expression, e.g., a dramatic increase in the expression of CCAAT/enhancer binding protein $\alpha(\mathrm{C} / \mathrm{EBP} \alpha)$ and peroxisome proliferator-activated receptor $\gamma(\operatorname{PPAR} \gamma)(6,7)$. Recently, it has been suggested that the mitogen-activated protein kinase (MAPK) signaling pathway regulates the expression of $\mathrm{C} / \mathrm{EBP} \alpha$ and PPAR $\gamma$ mRNA during adipogenesis (810). Murine 3T3-L1 preadipocytes have been frequently used to study the differentiation of preadipo-

* To whom correspondence should be addressed.

E-mail: fujimoto@gly.oups.ac.jp cytes into mature adipocytes in vitro (11-13).

There is a substantial body of circumstantial evidence that excess body fat is associated with an increased risk of suboptimal vitamin D status (14-16). $1 \alpha, 25$-Dihydroxy-cholecalciferol [ $\left.1 \alpha, 25-(\mathrm{OH})_{2}-\mathrm{VD}_{3}\right]$, the most active form of vitamin $\mathrm{D}_{3}$ metabolite, has previously been shown to regulate adipocyte differentiation. In early reports, a vitamin D receptor (VDR)-like molecule was detected in 3T3-L1 cells (17), and $1 \alpha, 25-$ $(\mathrm{OH})_{2}-\mathrm{VD}_{3}$ was shown to pose an inhibitory effect on 3T3-L1 differentiation on the basis of its inhibition of glycerophosphate dehydrogenase activity and triacylglycerol (TG) content $(17,18)$ or its ability to counter the stimulatory effect of the PPAR $\gamma$ ligand on 3T3-L1 differentiation (19). $1 \alpha, 25-(\mathrm{OH})_{2}-\mathrm{VD}_{3}$ was also able to inhibit adipocyte differentiation in mouse bone marrow stromal cells $(20)$.

In the present study, we aimed to clarify the requirement of the MAPK signaling pathway for $1 \alpha, 25-(\mathrm{OH})_{2}-$ $\mathrm{VD}_{3}$-induced modulation of adipocyte differentiation, using 3T3-L1 cells.

\section{MATERIALS AND METHODS}

Materials. Mouse 3T3-L1 preadipocytes were obtained from the European Collection of Cell Cultures, Wiltshire, UK. PPAR $\gamma$ Transcription Factor Assay kit was purchased from Cayman Chemical Co., Ann Arbor, 
MI, USA. Rabbit polyclonal anti-human PPAR $\gamma$ antibody and goat HRP-linked anti-rabbit IgG antibody were obtained from Santa Cruz Biotechnology, Santa Cruz, CA, USA, and Cell Signaling Technology, Beverly, MA, USA, respectively. A phospho-MAPK family antibody sampler kit was obtained from Cell Signaling Technology Japan, Tokyo, Japan. A transcriptor First Strand cDNA Synthesis kit and LightCycler FirstStart DNA Master $^{\text {plus }}$ SYBR green reagent were obtained from Roche Diagnostics, Indianapolis, IN, USA. TRIzol reagent and the primers for $\beta$-actin, adiponectin, tumor necrosis factor$\alpha$ (TNF- $\alpha$ ), plasminogen activator inhibitor-1 (PAI-1), $\operatorname{PPAR} \gamma, \mathrm{C} / \mathrm{EBP} \alpha, \mathrm{p} 38 \mathrm{MAPK} \alpha, \mathrm{p} 38 \mathrm{MAPK} \beta$, extracellular signal-regulated kinase 1/2 (ERK1/2) and c-jun N-terminal kinase (JNK) were purchased from Invitrogen, Carlsbad, CA, USA. $1 \alpha, 25-(\mathrm{OH})_{2}-\mathrm{VD}_{3}, 1 \alpha-\mathrm{OH}-\mathrm{VD}_{3}$ and $25-\mathrm{OH}-\mathrm{VD}_{3}$ were obtained from Sigma Chemical Co., St. Louis, MO, USA. Triglyceride E-test Wako was obtained from Wako Pure Chemical Industries, Ltd., Osaka, Japan. All other reagents were of analytical grade.

Adipocyte differentiation. 3T3-L1 preadipocytes were cultured at $37^{\circ} \mathrm{C}$ in a humidified atmosphere of $5 \%$ $\mathrm{CO}_{2} / 95 \%$ air. The cells were maintained in growth medium (DMEM with 10\% FBS and 1\% penicillin-streptomycin). Differentiation was induced according to the protocol enclosed with the 3T3-L1 preadipocytes from the European Collection of Cell Cultures: differentiation of the cells was initiated $2 \mathrm{~d}$ after confluence for $3 \mathrm{~d}$ in a growth medium containing $1 \mu \mathrm{g} / \mathrm{mL}$ insulin, $0.25 \mu \mathrm{M}$ dexamethasone and $0.5 \mathrm{mM}$ IBMX. This was followed by $2 \mathrm{~d}$ in a growth medium containing $1 \mu \mathrm{g} / \mathrm{mL}$ insulin. Thereafter, the cells were cultured in the growth medium for $2 \mathrm{~d}$.

Treatment with $1 \alpha, 25-(\mathrm{OH})_{2}-V_{3} .1 \alpha, 25-(\mathrm{OH})_{2}-\mathrm{VD}_{3}$ was prepared in $\mathrm{Me}_{2} \mathrm{SO}$ and added to the medium from day 3 (time of addition of insulin, dexamethasone and IBMX). The $\mathrm{Me}_{2} \mathrm{SO}$ concentration was maintained at $0.25 \%$ of the total volume, and preliminary experiments demonstrated no significant effects of $0.25 \%$ $\mathrm{Me}_{2} \mathrm{SO}$ on cell differentiation.

Measurement of TG. The TG contents in the cells were measured as described previously by us (21). The amount of TG, an index of lipid accumulation, was quantitatively measured using a Triglyceride E-test Wako kit following normalization by protein amounts and expressed as TG contents ( $\mu \mathrm{g} / \mathrm{mg}$ protein).

Measurement of PPAR $\gamma$, and phosphorylated (p-) MAPK protein expressions. Untreated or $1 \alpha, 25-(\mathrm{OH})_{2}-\mathrm{VD}_{3}-$ treated 3T3-L1 cells up to day 5 were washed with icecold PBS, and then lysed. The prepared lysates were mixed with an equal volume of solubilization buffer [20\% glycerol, 4\% SDS, 2\% 2-mercaptoethanol, $125 \mathrm{~mm}$ Tris/HCl (pH 6.8)] and boiled for $10 \mathrm{~min}$. Cell lysates were analyzed using a $7.5 \%$ polyacrylamide gel. Proteins were transferred to nitrocellulose membranes by electroblotting and the membranes were incubated overnight in TBS-T $(0.14 \mathrm{M} \mathrm{NaCl}, 20 \mathrm{~mm}$ Tris and $0.1 \%$ Tween 20, $\mathrm{pH}$ 7.4) containing the respective primary antibody (PPAR $\gamma$, p-p38MAPK, p-ERK or p-JNK antibody) and $3 \%$ nonfat dry milk. After incubation, the membranes were incubated with secondary goat HRPlinked anti-rabbit IgG antibody for $1 \mathrm{~h}$, followed by ECL (Amersham-Pharmacia Corp., Buckingham, UK).

Measurement of nuclear bioactive PPAR $\gamma$. Bioactive PPAR $\gamma$ in nuclear extract of 3T3-L1 cells was determined as described in our previous paper (21). Briefly, the nuclear fractions from 3T3-L1 cells were separated using the Nuclear Extraction kit (Marligen Biosciences Inc., Rockville, MD, USA). Bioactive PPAR $\gamma$ in the nucleus was measured using the PPAR $\gamma$ Transcription Factor Assay kit.

Measurement of mRNA expressions. Untreated or $1 \alpha, 25-(\mathrm{OH})_{2}-\mathrm{VD}_{3}$-treated 3T3-L1 cells up to day 5 were washed with ice-cold PBS. Total cellular RNA was prepared using TRIzol reagent. One microgram of total RNA was reverse transcribed into cDNA using a Transcriptor First Strand cDNA Synthesis kit. The concentration and quality of the purified total RNA were determined spectrophotometrically at $260 \mathrm{~nm}$ and by the $\mathrm{OD}_{\text {260:280 }}$ ratio. mRNA expression was measured by a real time RT-PCR using a LightCycler FirstStart DNA Master $^{\text {plus }}$ SYBR green reagent and LightCycler instrument (Roche). Results were expressed as relative amount of the target mRNA to $\beta$-action mRNA, and the values in the presence or absence of drugs were expressed as relative amount to the None value (no addition of insulin, dexamethasone or IBMX).

The primers for $\beta$-actin, adiponectin, TNF- $\alpha$, PAI- 1 , $\operatorname{PPAR} \gamma, \mathrm{C} / \mathrm{EBP} \alpha, \mathrm{p} 38 \mathrm{MAPK} \alpha, \mathrm{p} 38 \mathrm{MAPK} \beta, \mathrm{ERK} 1 / 2$ and

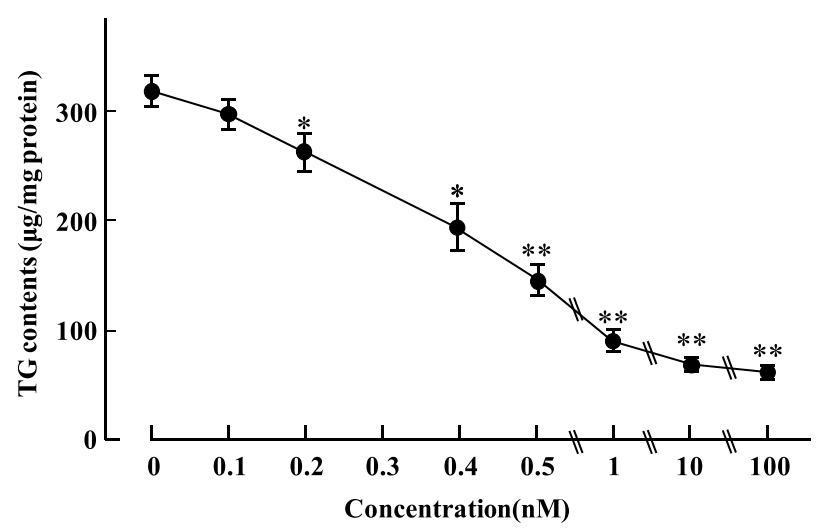

Fig. 1. Alterations in TG contents of 3T3-L1 cells treated with $1 \alpha, 25-(\mathrm{OH})_{2}-\mathrm{VD}_{3}$. The differentiation of 3T3-L1 preadipocytes was initiated $2 \mathrm{~d}$ after confluence for $3 \mathrm{~d}$ in growth medium containing $1 \mu \mathrm{g} / \mathrm{mL}$ insulin, $0.25 \mu \mathrm{M}$ dexamethasone and $0.5 \mathrm{mM}$ IBMX. This was followed by $2 \mathrm{~d}$ in growth medium containing $1 \mu \mathrm{g} / \mathrm{mL}$ insulin. Thereafter, the cells were cultured in the growth medium for $2 \mathrm{~d} .1 \alpha, 25-(\mathrm{OH})_{2}-\mathrm{VD}_{3}$ was added to the medium from day 3 (time of addition of insulin, dexamethasone and IBMX) to day 9 (end point of the experiment). The treated cells were lysed with lysis buffer, and the TG contents were measured using a Triglyceride E-test Wako kit. The data represent the mean \pm SE of four experiments. ${ }^{*} p<0.05,{ }^{* *} p<0.01$; significantly different from the corresponding value in the absence of $1 \alpha, 25-(\mathrm{OH})_{2}-\mathrm{VD}_{3} .1 \alpha, 25-(\mathrm{OH})_{2}-\mathrm{VD}_{3}$, $1 \alpha, 25$-dihydroxy-cholecalciferol; TG, triacylglycerol; IBMX, 3-isobutyl-1-methyl-xanthine. 


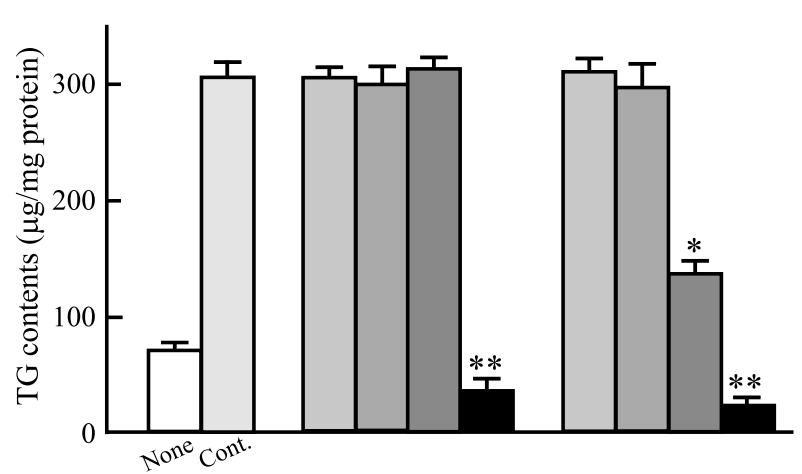

\begin{tabular}{|c|c|c|c|c|c|c|c|}
\hline $\mathrm{VD}_{3}(\mathrm{nM})$ & 10 & - & - & - & 100 & - & - \\
\hline $25-\mathrm{OH}-\mathrm{VD}_{3}(\mathrm{nM})$ & - & 10 & - & - & - & 100 & - \\
\hline $1 \alpha-\mathrm{OH}-\mathrm{VD}_{3}(\mathrm{nM})$ & - & - & 10 & - & - & - & 100 \\
\hline $1 \alpha, 25-(\mathrm{OH})_{2}-\mathrm{VD}_{3}(\mathrm{nM})$ & . & _ & _ & 10 & _ & _ & _ \\
\hline
\end{tabular}

Fig. 2. Alterations in TG contents of 3T3-L1 cells treated with $1 \alpha, 25-(\mathrm{OH})_{2}-\mathrm{VD}_{3}$ analogs. The differentiation of 3T3-L1 preadipocytes was initiated $2 \mathrm{~d}$ after confluence for $3 \mathrm{~d}$ in growth medium containing $1 \mu \mathrm{g} /$ $\mathrm{mL}$ insulin, $0.25 \mu \mathrm{M}$ dexamethasone and $0.5 \mathrm{~mm}$ IBMX. This was followed by $2 \mathrm{~d}$ in growth medium containing $1 \mu \mathrm{g} / \mathrm{mL}$ insulin. Thereafter, the cells were cultured in the growth medium for $2 \mathrm{~d} . \mathrm{VD}_{3}, 25-\mathrm{OH}-\mathrm{VD}_{3}$, $1 \alpha-\mathrm{OH}-\mathrm{VD}_{3}$ or $1 \alpha, 25-(\mathrm{OH})_{2}-\mathrm{VD}_{3}(10$ and $100 \mathrm{nM})$ was added to the medium from day 3 (time of addition of insulin, dexamethasone and IBMX) to day 9 (end point of the experiment). The treated cells were lysed with lysis buffer, and the TG contents were measured using a Triglyceride E-test Wako kit. The data represent the mean \pm SE of five experiments. ${ }^{*} p<0.05$, ${ }^{* *} p<0.01$; significantly different from Control (Cont.). $\mathrm{VD}_{3}$, cholecalciferol; 25-OH-VD 3 , 25-hydroxy-cholecalciferol; $1 \alpha$ $\mathrm{OH}-\mathrm{VD}_{3}, 1 \alpha$-hydroxy-cholecalciferol; $1 \alpha, 25-(\mathrm{OH})_{2}-\mathrm{VD}_{3}$, 1 $\alpha, 25$-dihydroxy-cholecalciferol; TG, triacylglycerol; IBMX, 3-isobutyl-1-methyl-xanthine.
JNK were as follows: $\beta$-actin, 5'-ACACCCCAGCCATGTACG-3', 5'-TGGTGGTGAAGCTGTAGCC-3'; adiponectin, 5'-GGCAGGCATCCCAGGACATC-3', 5'-TCTCACCCTTAGGACCAAGAAGAC-3'; TNF- $\alpha, 5^{\prime}$-ACCTTTCCAGATTCTTCCCTGAG-3', 5'-CCCGGCCTTCCAAATAAATACATT-3'; PAI-1, 5'-CCTCTTCATGGGCCAAGT-3', 5'-GGTAAGGAGGAGTTGCCTTC-3'; PPAR $\gamma$, 5'-GTGAAGCCCATCGAGGACA-3', 5'-TGGAGCACCTTGGCGAACA-3'; $\mathrm{C} / \mathrm{EBP} \alpha, 5^{\prime}$-ATGGTTTCGGGTCGCTGGAT-3', 5'-CCACGGCCTGACTCCCTCAT-3'; p38MAPK $\alpha$, 5'-CCTTGACCAAGAAGAAATG-3', 5'-ACAGACGAACAGACAGACAC3'; p38MAPK $\beta$, 5'-ACCAAGAAGTCCTTAGCTTC-3', 5'GTAGAGTTTCTCAAGGCAAG-3'; ERK1/2, 5'-GCTCACCCTTACCTGGAACA-3', 5'-GGACCAGATCCAAAAGGACA-3'; JNK, 5'-AATGGTTTGCCACAAAATCC-3', 5'GAGTCAGCTGGGAAAAGCAC-3'.

Statistical analysis. Results are the means \pm SE. The significance of differences between two groups was assessed using the $t$-test, and differences between multiple groups were assessed by one-way analysis of variance (ANOVA) followed by Scheffe's multiple range test. $p$-values less than 0.05 were considered significant.

\section{RESULTS}

Figure 1 shows the effect of $1 \alpha, 25-(\mathrm{OH})_{2}-\mathrm{VD}_{3}$ on the TG contents, a marker of lipid accumulation, in 3T3-L1 cells. An incubation of 3T3-L1 preadipocytes with insulin, dexamethasone and IBMX (Cont.) increased the TG contents by 4-5 fold compared to the None value (no addition of insulin, dexamethasone or IBMX) (data not shown). At concentrations ranging from 0.1 to $100 \mathrm{nM}$, $1 \alpha, 25-(\mathrm{OH})_{2}-\mathrm{VD}_{3}$ dose-dependently inhibited the TG contents. The reduction of TG accumulation was appar-

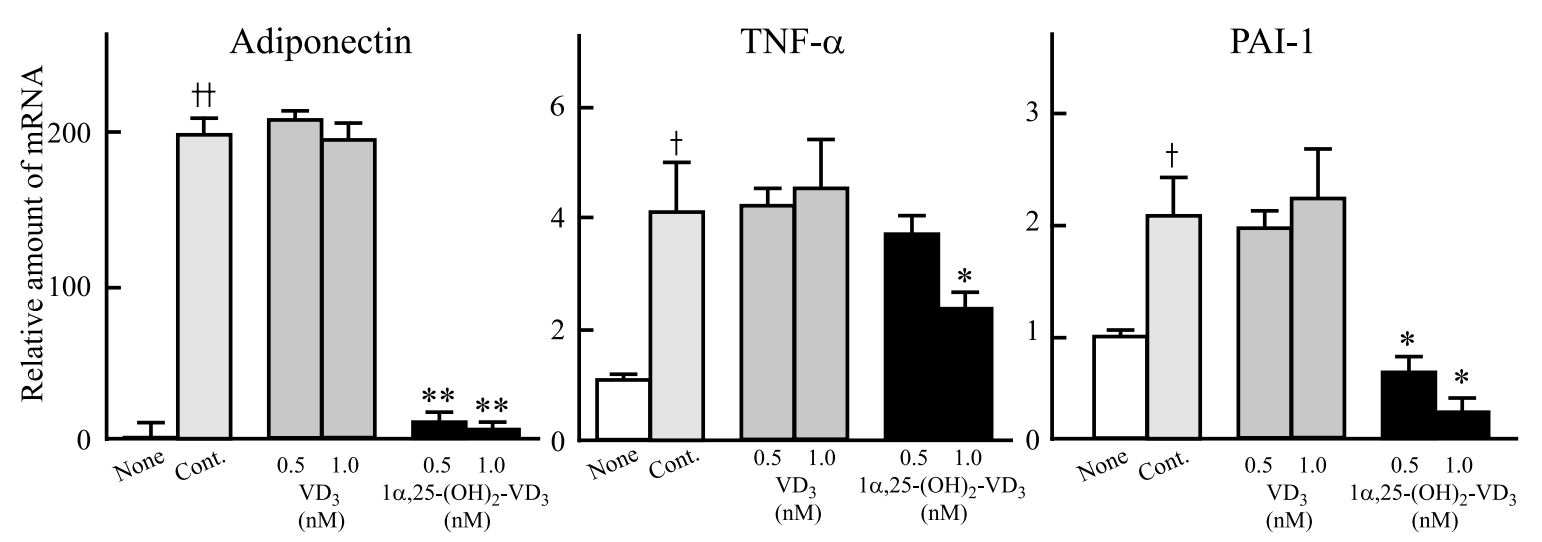

Fig. 3. Alterations in mRNA levels of adiponectin, TNF- $\alpha$ and PAI- 1 of 3T3-L1 cells treated with $\mathrm{VD}_{3}$ or $1 \alpha, 25-(\mathrm{OH})_{2}-\mathrm{VD}{ }_{3}$. The differentiation of 3T3-L1 preadipocytes was initiated $2 \mathrm{~d}$ after confluence for $3 \mathrm{~d}$ in growth medium containing $1 \mu \mathrm{g} /$ $\mathrm{mL}$ insulin, $0.25 \mu \mathrm{M}$ dexamethasone and $0.5 \mathrm{mM}$ IBMX. This was followed by $2 \mathrm{~d}$ in growth medium containing $1 \mu \mathrm{g} / \mathrm{mL}$ insulin. Thereafter, the cells were cultured in the growth medium for $2 \mathrm{~d} . \mathrm{VD}_{3}$ or $1 \alpha, 25-(\mathrm{OH})_{2}-\mathrm{VD}_{3}(0.5$ and $1.0 \mathrm{nM})$ was added to the medium from day 3 (time of addition of insulin, dexamethasone and IBMX) to day 5. Total RNA was extracted with TRIzol reagent, and mRNA levels were measured by real time RT-PCR using a Transcriptor First Strand cDNA Synthesis kit and LightCycler Firststart DNA Master ${ }^{\text {PUS }}$ SYBR Green I kit. Results are expressed as relative amount of the target mRNA to $\beta$-action mRNA, and the values in the presence or absence of drugs are expressed as relative amount to the None value (no addition of insulin, dexamethasone or IBMX). The data represent the mean \pm SE from three or four experiments. ${ }^{\dagger} p<0.05$, ${ }^{\dagger} p<0.01$; significantly different from None. ${ }^{*} p<0.05,{ }^{* *} p<0.01$; significantly different from Control (Cont.). $\mathrm{VD}_{3}$, cholecalciferol; $1 \alpha, 25-(\mathrm{OH})_{2}-\mathrm{VD}_{3}, 1 \alpha, 2$-dihydroxy-cholecalciferol; TNF- $\alpha$, tumor necrosis factor- $\alpha$; PAI- 1 , plasminogen activator inhibitor-1; IBMX, 3-isobutyl-1-methyl-xanthine. 

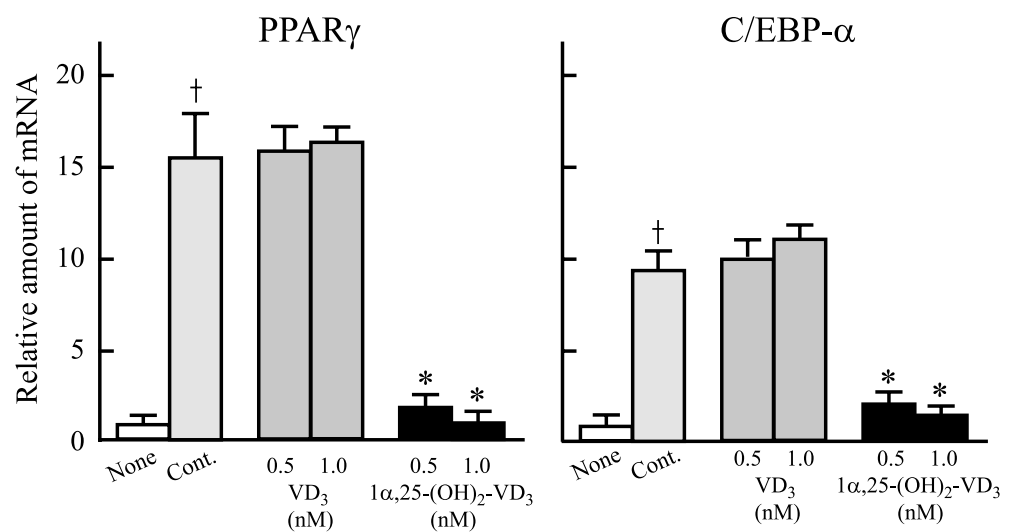

Fig. 4. Alterations in PPAR $\gamma$ and C/EBP- $\alpha$ mRNA levels of 3T3-L1 cells treated with $\mathrm{VD}_{3}$ or $1 \alpha, 25-(\mathrm{OH})_{2}-\mathrm{VD}_{3}$. The differentiation of 3T3-L1 preadipocytes was initiated $2 \mathrm{~d}$ after confluence for $3 \mathrm{~d}$ in growth medium containing $1 \mu \mathrm{g} / \mathrm{mL} \mathrm{insu}-$ lin, $0.25 \mu \mathrm{M}$ dexamethasone and $0.5 \mathrm{mM}$ IBMX. This was followed by $2 \mathrm{~d}$ in growth medium containing $1 \mu \mathrm{g} / \mathrm{mL}$ insulin. Thereafter, the cells were cultured in the growth medium for $2 \mathrm{~d} . \mathrm{VD}_{3}$ or $1 \alpha, 25-(\mathrm{OH})_{2}-\mathrm{VD}_{3}(0.5$ and $1.0 \mathrm{nM})$ was added to the medium from day 3 (time of addition of insulin, dexamethasone and IBMX) to day 5. Total RNA was extracted with TRIzol reagent, and mRNA levels were measured by a real time RT-PCR using a Transcriptor First Strand cDNA Synthesis kit and LightCycler Firststart DNA Master ${ }^{\text {PLUS }}$ SYBR Green I kit. Results are expressed as relative amount of the target mRNA to $\beta$-action mRNA, and the values in the presence or absence of drugs are expressed as relative amount to the None value (no addition of insulin, dexamethasone and IBMX). The data represent the mean \pm SE from four experiments. ${ }^{\dagger} p<0.01$; significantly different from None. ${ }^{*} p<0.01$; significantly different from Control (Cont.). $\mathrm{VD}_{3}$, cholecalciferol; $1 \alpha, 25-(\mathrm{OH})_{2}-\mathrm{VD}_{3}, 1 \alpha, 25$-dihydroxy-cholecalciferol; PPAR $\gamma$, peroxisome proliferator-activated receptor $\gamma ; \mathrm{C} / \mathrm{EBP} \alpha$, CCAAT-enhancer binding protein $\alpha$; IBMX, 3-isobutyl-1-methyl-xanthine.
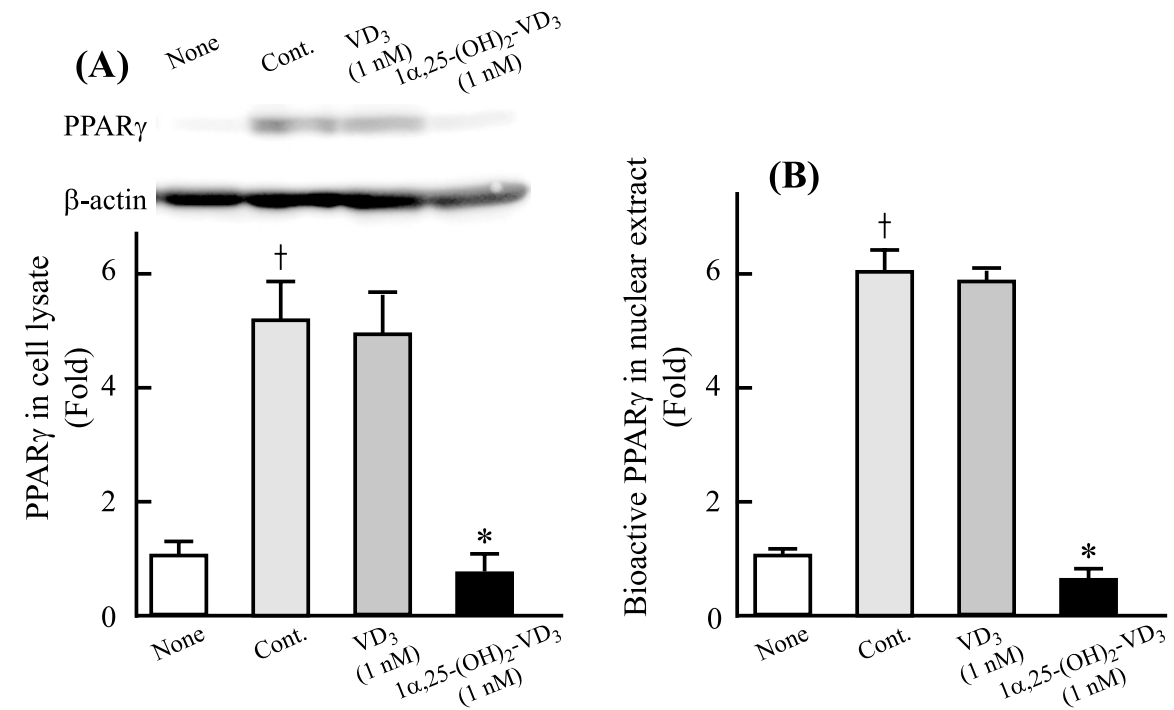

Fig. 5. Alterations in protein expression of PPAR $\gamma$ in cell lysates (A) and in bioactive PPAR $\gamma$ in nuclear extract (B) of 3T3$\mathrm{L} 1$ cells treated with $\mathrm{VD}_{3}$ or $1 \alpha, 25-(\mathrm{OH})_{2}-\mathrm{VD}_{3}$. The differentiation of 3T3-L1 preadipocytes was initiated $2 \mathrm{~d}$ after confluence for $3 \mathrm{~d}$ in growth medium containing $1 \mu \mathrm{g} / \mathrm{mL}$ insulin, $0.25 \mu \mathrm{M}$ dexamethasone and $0.5 \mathrm{mM}$ IBMX. This was followed by $2 \mathrm{~d}$ in growth medium containing $1 \mu \mathrm{g} / \mathrm{mL}$ insulin. Thereafter, the cells were cultured in the growth medium for $2 \mathrm{~d} . \mathrm{VD}_{3}$ or $1 \alpha, 25-(\mathrm{OH})_{2}-\mathrm{VD}_{3}(1.0 \mathrm{nM})$ was added to the medium from day 3 (time of addition of insulin, dexamethasone and IBMX) to day 5. (A) Detection of protein expression was performed with Western blotting. The density of a PPAR $\gamma$ band was divided by that of the respective $\beta$-actin band. Data represent ratios to the None value (no addition of insulin, dexamethasone or IBMX). (B) The nuclear fractions from 3T3-L1 cells were separated using the Nuclear Extraction kit. Bioactive PPAR $\gamma$ in the nucleus was measured using the PPAR $\gamma$ Transcription Factor Assay kit. Data represent ratios to the None value. The data represent the mean \pm SE from three or four experiments. ${ }^{\dagger} p<0.01$; significantly different from None; ${ }^{*} p<0.01$; significantly different from Control (Cont.). $\mathrm{VD}_{3}$, cholecalciferol; $1 \alpha, 25-(\mathrm{OH})_{2}-\mathrm{VD}_{3}, 1 \alpha, 25$-dihydroxycholecalciferol; PPAR $\gamma$, peroxisome proliferator-activated receptor $\gamma$; IBMX, 3-isobutyl-1-methyl-xanthine.

ent even at a concentration of $0.2 \mathrm{~nm}(17 \%$ inhibition). Yoshimoto and Norman (22), and Tuohimaa et al. (23) have reported that the physiological concentration of $1 \alpha, 25-(\mathrm{OH})_{2}-\mathrm{VD}_{3}$ in the plasma of chicks and humans is about 125 or $100 \mathrm{pM}$, respectively. Thus, it seems likely that $1 \alpha, 25-(\mathrm{OH})_{2}-\mathrm{VD}_{3}$ in the physiological concentration range acts as an inhibitor of TG accumulation in adipocytes.

Figure 2 illustrates the effects of $\mathrm{VD}_{3}, 25-\mathrm{OH}-\mathrm{VD}_{3}$ and $1 \alpha-\mathrm{OH}-\mathrm{VD}_{3}$ in comparison with $1 \alpha, 25-(\mathrm{OH})_{2}-\mathrm{VD}_{3}$ on 

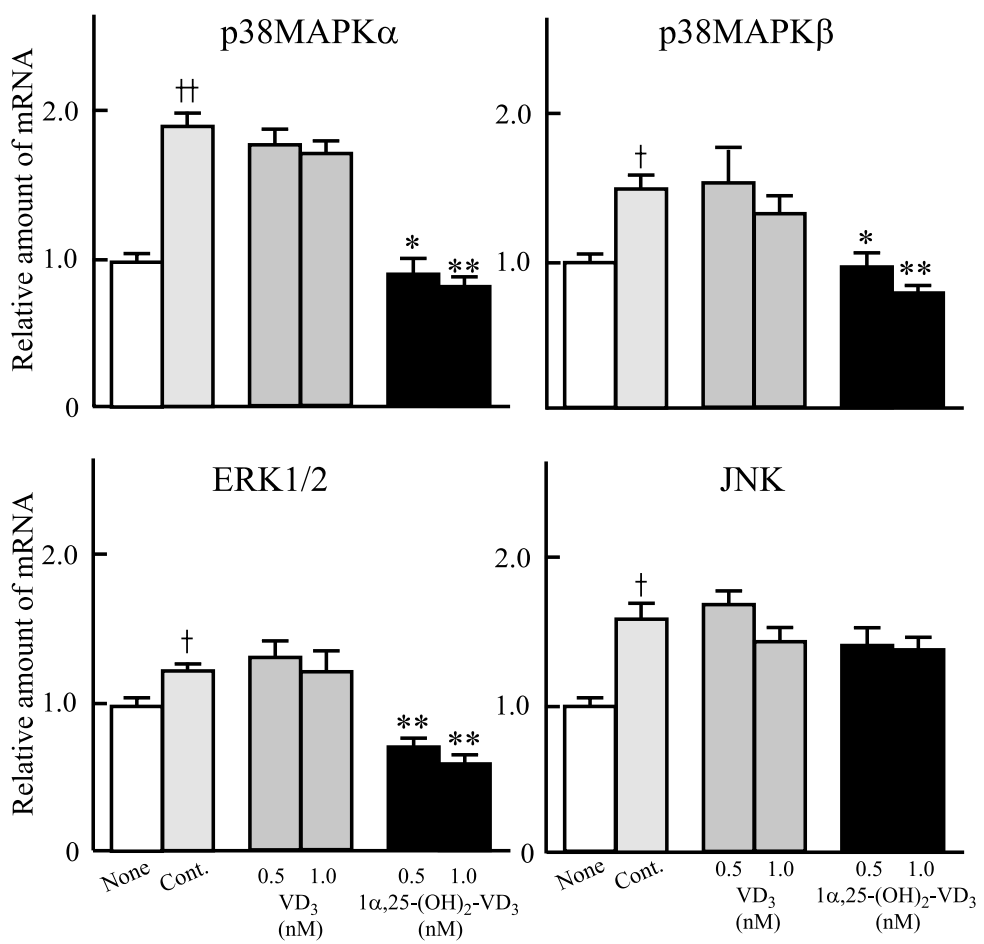

Fig. 6. Alterations in p38MAPK $\alpha$, p38MAPK $\beta$, ERK1/2 and JNK mRNA levels of 3T3-L1 cells treated with VD 3 or $1 \alpha, 25-$ $(\mathrm{OH})_{2}-\mathrm{VD}_{3}$. The differentiation of 3T3-L1 preadipocytes was initiated $2 \mathrm{~d}$ after confluence for $3 \mathrm{~d}$ in growth medium containing $1 \mu \mathrm{g} / \mathrm{mL}$ insulin, $0.25 \mu \mathrm{M}$ dexamethasone and $0.5 \mathrm{mM}$ IBMX. This was followed by $2 \mathrm{~d}$ in growth medium containing $1 \mu \mathrm{g} / \mathrm{mL}$ insulin. Thereafter, the cells were cultured in the growth medium for $2 \mathrm{~d}$. $\mathrm{VD}_{3}$ or $1 \alpha, 25-(\mathrm{OH})_{2}-\mathrm{VD}_{3}(0.5$ and $1.0 \mathrm{nM}$ ) was added to the medium from day 3 (time of addition of insulin, dexamethasone and IBMX) to day 5 . Total RNA was extracted with TRIzol reagent, and mRNA levels were measured by real time RT-PCR using a Transcriptor First Strand cDNA Synthesis kit and LightCycler Firststart DNA Master ${ }^{\text {PLUS }}$ SYBR Green I kit. Results are expressed as relative amount of the target mRNA to $\beta$-action mRNA, and the values in the presence or absence of drugs are expressed as relative amount to the None value (no addition of insulin, dexamethasone and IBMX). The data represent the mean \pm SE from four experiments. ${ }^{\dagger} p<0.05,{ }^{\dagger \dagger} p<0.01$; significantly different from None. ${ }^{*} p<0.05,{ }^{* *} p<0.01$; significantly different from Control (Cont.). $\mathrm{VD}_{3}$, cholecalciferol; $1 \alpha, 25-(\mathrm{OH})_{2}-\mathrm{VD}_{3}, 1 \alpha, 25$-dihydroxy-cholecalciferol; p38MAPK $\alpha$, p38 mitogenactivated protein kinase $\alpha$; p38MAPK $\beta$, p38 mitogen-activated protein kinase $\beta$; ERK1/2, extracellular signal-regulated kinase 1/2; JNK, c-jun N-terminal kinase; IBMX, 3-isobutyl-1-methyl-xanthine.

TG contents in 3T3-L1 cells. At a concentration of $10 \mathrm{nM}, \mathrm{VD}_{3}, 25-\mathrm{OH}-\mathrm{VD}_{3}$ and $1 \alpha-\mathrm{OH}-\mathrm{VD}_{3}$ showed no significant effect on the TG accumulation, whereas $1 \alpha, 25-(\mathrm{OH})_{2}-\mathrm{VD}_{3}$ inhibited it by $88 \%$. Although $1 \alpha-$ $\mathrm{OH}-\mathrm{VD}_{3}$ at a concentration of $100 \mathrm{~nm}$ reduced the TG accumulation (56\% inhibition), the inhibitory effect was weaker than that of $1 \alpha, 25-(\mathrm{OH})_{2}-\mathrm{VD}_{3}(92 \%$ inhibition). $\mathrm{VD}_{3}$ is produced in the skin in response to ultraviolet $\mathrm{B}$ radiation and then converted in the liver to 25 $\mathrm{OH}-\mathrm{VD}_{3}$, which acts as a precursor for the renal production of $1 \alpha, 25-(\mathrm{OH})_{2}-\mathrm{VD}_{3}$. Therefore, the results of Fig. 2 indicate that, of the two hydroxyl groups, the 1hydroxyl position is important for the $1 \alpha, 25-(\mathrm{OH})_{2}-\mathrm{VD}_{3}$ effect, and that only $1 \alpha, 25-(\mathrm{OH})_{2}-\mathrm{VD}_{3}$ formed naturally in the cell body, but not an intermediate, can down-regulate the TG accumulation.

Figure 3 illustrates the effects of $\mathrm{VD}_{3}$ and $1 \alpha, 25$ $(\mathrm{OH})_{2}-\mathrm{VD}_{3}$ on the mRNA expressions of adiponectin, TNF- $\alpha$ and PAI-1. After incubation with insulin, dexamethasone and IBMX, 3T3-L1 adipocytes produced more mRNA expressions of adiponectin, TNF- $\alpha$ and PAI-1. $\mathrm{VD}_{3}$ at concentrations of 0.5 and $1.0 \mathrm{~nm}$ had no significant effect on these three mRNA expression lev- els, but $1 \alpha, 25-(\mathrm{OH})_{2}-\mathrm{VD}_{3}$ at 0.5 and/or $1.0 \mathrm{nM}$ inhibited all of them (adiponectin mRNA, 94 and 96\% inhibition; TNF- $\alpha$ mRNA, 8 and $41 \%$ inhibition; PAI1 mRNA, 69 and 86\% inhibition). Adipose tissue has been identified as an endocrine organ that secretes various kinds of bioactive molecules called adipocytokines $(4,5)$. After differentiation, mature 3T3-L1 adipocytes secrete adiponectin and TNF- $\alpha(6,7)$. On the other hand, PAI-1 is an important component of the plasminogen/plasmin system as it is the main inhibitor of tissue-type and urokinase-type plasminogen activator. Its plasma level is strongly correlated with parameters that define insulin resistance syndrome, in particular the Body Mass Index and visceral accumulation of body fat, suggesting that PAI-1 may be an adipose tissue-derived circulating peptide (24). PAI-1 has been reported to be produced in 3T3-L1 cells after differentiation (25). Thus, the results of Fig. 3 demonstrate that $1 \alpha, 25-$ $(\mathrm{OH})_{2}-\mathrm{VD}_{3}$ under physiological conditions inhibits the differentiation of 3T3-L1 preadipocytes into mature adipocytes.

In an attempt to clarify the mechanism by which $1 \alpha, 25-(\mathrm{OH})_{2}-\mathrm{VD}_{3}$ inhibits the adipocyte differentiation, 


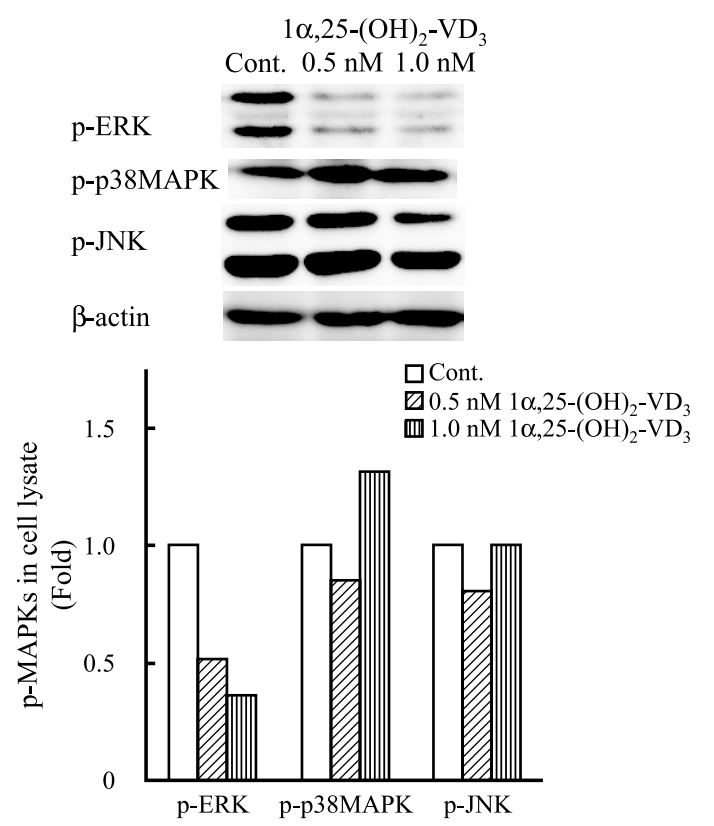

Fig. 7. Alterations in protein expressions of phosphorylated (p-) ERK, p-p38MAPK, p-JNK in cell lysates of 3T3-L1 cells treated with $1 \alpha, 25-(\mathrm{OH})_{2}-\mathrm{VD}_{3}$. The differentiation of 3T3-L1 preadipocytes was initiated $2 \mathrm{~d}$ after confluence for $3 \mathrm{~d}$ in growth medium containing $1 \mu \mathrm{g} / \mathrm{mL}$ insulin, $0.25 \mu \mathrm{M}$ dexamethasone and $0.5 \mathrm{~mm}$ IBMX. This was followed by $2 \mathrm{~d}$ in growth medium containing $1 \mu \mathrm{g} / \mathrm{mL}$ insulin. Thereafter, the cells were cultured in the growth medium for $2 \mathrm{~d} .1 \alpha, 25-(\mathrm{OH})_{2}-\mathrm{VD}_{3}$ $(1.0 \mathrm{nM})$ was added to the medium from day 3 (time of addition of insulin, dexamethasone and IBMX) to day 5 . Detection of protein expression was performed with Western blotting. The density of respective MAPK band was divided by that of the respective $\beta$-actin band. Data represent ratios to the Control value (Cont., addition of insulin, dexamethasone and IBMX). The data represent the mean from two experiments. $1 \alpha, 25-(\mathrm{OH})_{2}-\mathrm{VD}_{3}$, 1 $\alpha, 25$-dihydroxy-cholecalciferol; p38MAPK, p38 mitogen-activated protein kinase; ERK, extracellular signalregulated kinase; JNK, c-jun N-terminal kinase; IBMX, 3-isobutyl-1-methyl-xanthine.

we measured the mRNA and/or protein expressions of transcriptional regulators involved in adipocyte differentiation (Figs. 4-7). Figures 4 and 5 illustrate the effects of $\mathrm{VD}_{3}$ and $1 \alpha, 25-(\mathrm{OH})_{2}-\mathrm{VD}_{3}$ on the mRNA and/ or protein expressions of PPAR $\gamma$ and C/EBP- $\alpha$. As shown in Fig. 4, the addition of insulin, dexamethasone and IBMX increased PPAR $\gamma$ and C/EBP- $\alpha$ mRNA levels. $\mathrm{VD}_{3}$ at 0.5 and $1.0 \mathrm{nM}$ had no significant effect on PPAR $\gamma$ or C/EBP- $\alpha$ mRNA levels, whereas $1 \alpha, 25-(\mathrm{OH})_{2-}$ $\mathrm{VD}_{3}$ at the same concentrations inhibited these two mRNA levels by 89 and $95 \%$ for PPAR $\gamma$, and 79 and $85 \%$ for $\mathrm{C} / \mathrm{EBP} \alpha$. Also, as depicted in Fig. 5, the addition of insulin, dexamethasone and IBMX significantly enhanced the PPAR $\gamma$ in cell lysates and the bioactive PPAR $\gamma$ in the nucleus of 3T3-L1 cells. The co-addition of $1 \alpha, 25-(\mathrm{OH})_{2}-\mathrm{VD}_{3}(1 \mathrm{nM})$, but not $\mathrm{VD}_{3}(1 \mathrm{nM})$, with insulin, dexamethasone and IBMX decreased them by 86 and $89 \%$, respectively. These results show that $1 \alpha, 25-(\mathrm{OH})_{2}-\mathrm{VD}_{3}$ inhibits adipocyte differentiation via the $\mathrm{C} / \mathrm{EBP}-\alpha$ and PPAR $\gamma$ pathway. This is in accordance with previous findings reported by Blumberg et al. (26).

Furthermore, Figs. 6 and 7 show the relationship between the MAPK pathway and $1 \alpha, 25-(\mathrm{OH})_{2}-\mathrm{VD}_{3}$-induced inhibition of adipocyte differentiation. As shown in Fig. 6, after incubation with insulin, dexamethasone and IBMX, 3T3-L1 adipocytes produced more mRNA expressions of p38MAPK $\alpha$, p38MAPK $\beta$, ERK $1 / 2$ and JNK. The increases in mRNA levels of p38MAPK $\alpha$, p38MAPK $\beta$ and ERK1/2 were inhibited by the addition of $1 \alpha, 25-(\mathrm{OH})_{2}-\mathrm{VD}_{3}$ (0.5 and $1.0 \mathrm{nM}$ : p38MAPK $\alpha, 52$ and $57 \%$ inhibition; p38MAPK $\beta, 36$ and $48 \%$ inhibition; ERK1/2, 43 and $51 \%$ inhibition) but not $\mathrm{VD}_{3}$. In contrast, neither $\mathrm{VD}_{3}$ nor $1 \alpha, 25-(\mathrm{OH})_{2}-\mathrm{VD}_{3}$ had a significant effect on the increase in JNK mRNA level induced by insulin, dexamethasone or IBMX. 1 $\alpha, 25-$ $(\mathrm{OH})_{2}-\mathrm{VD}_{3}$ at 0.5 and $1.0 \mathrm{nM}$ also decreased p-ERK protein expression level, whereas there was no reduction in the protein expression levels of p-p38MAPK and p-JNK (Fig. 7). The results of Figs. 6 and 7 indicate that the decreases in mRNA level and phosphorylation of ERK are closely related to the $1 \alpha, 25-(\mathrm{OH})_{2}-\mathrm{VD}_{3}$-induced inhibition of adipocyte differentiation.

\section{DISCUSSION}

There are some reports concerning the modulatory role of $1 \alpha, 25-(\mathrm{OH})_{2}-\mathrm{VD}_{3}$ on adipocyte differentiation (14-20). However, the molecular mechanism of $1 \alpha, 25-$ $(\mathrm{OH})_{2}-\mathrm{VD}_{3}$-induced modulation remains unclear. The differentiation of preadipocytes into mature insulinresponsive adipocytes involves exposure of a confluent, quiescent population of cells to a variety of effectors that activate a cascade of transcription factors commencing with $\mathrm{C} / \mathrm{EBP}-\beta$ and $\mathrm{C} / \mathrm{EBP}-\delta$, which ultimately induce the expression of $\mathrm{C} / \mathrm{EBP}-\alpha$ and $\operatorname{PPAR} \gamma(6,7)$. Although, several laboratories have investigated the role of ERK1/2 MAPK in regulating adipogenesis, their conclusions are somewhat controversial. Some studies claim that activation of ERK1/2 MAPK by various effectors blocks adipogenesis $(27,28)$, whereas others suggest that it promotes preadipocyte differentiation $(8,9)$. The distinguishing factor might involve the precise timing of MAPK activation during the initial stages of the differentiation process. For instance, effectors that activate the ERK1/2 pathway at late stages of adipogenesis are likely to block adipogenic gene expression due to a MAPK-dependent phosphorylation of $\operatorname{PPAR} \gamma(29,30)$. Activation of the pathway early in adipogenesis prior to PPAR $\gamma$ expression might, on the other hand, promote differentiation by activating transcription factors operating to initiate $\mathrm{C} / \mathrm{EBP}-\alpha$ and PPAR $\gamma$ expression (10).

In the present study, $1 \alpha, 25-(\mathrm{OH})_{2}-\mathrm{VD}_{3}$ potently reduced the mRNA and/or protein expressions of $\mathrm{C} /$ $\operatorname{EBP} \alpha$ and $\operatorname{PPAR} \gamma$, and the nuclear translocation of $\operatorname{PPAR} \gamma$. Furthermore, it inhibited the mRNA expression and phosphorylation of ERK, one of the MAPKs. These results suggest a possible role of ERK in mediating $1 \alpha, 25-(\mathrm{OH})_{2}-\mathrm{VD}_{3}$-induced alteration in adipocyte differentiation.

Sato and Hiragun (17) have reported that $1 \alpha, 25-$ 
$(\mathrm{OH})_{2}-\mathrm{VD}_{3}$ inhibited morphologic and enzymatic expression during differentiation of 3T3-L1 preadipocytes to mature adipocytes, and that the action of $1 \alpha, 25-(\mathrm{OH})_{2}-\mathrm{VD}_{3}$ on the adipocyte differentiation may result from a receptor-mediated event. Blumberg et al. (26) have shown that in the presence of $1 \alpha, 25-(\mathrm{OH})_{2-}$ $\mathrm{VD}_{3}$, VDR blocks adipogenesis of 3T3-L1 cells by downregulating the $\mathrm{C} / \mathrm{EBP}-\alpha-\mathrm{PPAR} \gamma$ pathway. Thus, it appears that the potent reduction of adipocyte differentiation induced by $1 \alpha, 25-(\mathrm{OH})_{2}-\mathrm{VD}_{3}$ shown in the present study is mediated by the VDR.

Previously, ERK has been reported to regulate the action of C/EBP- $\alpha$ and/or PPAR $\gamma$ through a direct (29, $30)$ or indirect (10) mechanism. However, in the present study, it is unclear whether the $1 \alpha, 25-(\mathrm{OH})_{2}-$ $\mathrm{VD}_{3}$-induced inhibition of adipocyte differentiation can be ascribed to a depression on the ERK effect. Further studies are needed to clarify this problem.

The present findings may provide new information to extend the ongoing debate as to the mechanisms through which $1 \alpha, 25-(\mathrm{OH})_{2}-\mathrm{VD}_{3}$ plays functional roles both physiologically and pharmacologically in animal and human bodies.

\section{REFERENCES}

1) Larsson B, Svardsudd K, Welin I, Wilhelmsen L, Bjorntorp P, Tibblin G. 1984. Abdominal adipose tissue distribution, obesity, and risk of cardiovascular disease and death: 13 year follow up of participants in the study of men born in 1913. Brit Med J 288: 1401-1404.

2) Kahn SE, Hull RL, Utzschneider KM. 2006. Mechanisms linking obesity to insulin resistance and type 2 diabetes. Nature 444: 840-846.

3) Takamura T, Nohara E, Nagai Y, Kobayashi K. 2001. Stage-specific effects of a thiazolidinedione on proliferation, differentiation and PPAR $\gamma$ mRNA expression in 3T3-L1 adipocytes. Eur J Pharmacol 422: 23-29.

4) Yamauchi T, Kamon J, Waki H, Murakami K, Motojima K, Komeda K, Ide T, Kubota N, Terauchi Y, Tobe K, Miki H, Tsuchida A, Akanuma Y, Nagai R, Kimura S, Kadowaki T. 2001. The mechanisms by which both heterozygous peroxisome proliferator-activated receptor $\gamma$ $(\operatorname{PPAR} \gamma)$ deficiency and PPAR $\gamma$ agonist improve insulin resistance. J Biol Chem 276: 41245-41254.

5) Guerre-Millo M. 2004. Adipose tissue and adipokines: for better or worse. Diabetes Metab 30: 13-19.

6) Morrison RF, Farmer SR. 1999. Insights into the transcriptional control of adipocyte differentiation. J Cell Biochem 32-33: 59-67.

7) Rosen ED, Walkey CJ, Puigserver P, Spiegelman BM. 2000. Transcriptional regulation of adipogenesis. Genes Dev 14: 1293-1307.

8) Bost F, Caron L, Marchetti I, Dani C, Le Marchand-Brustel Y, Binétruy B. 2002. Retinoic acid activation of the ERK pathway is required for embryonic stem cell commitment into the adipocyte lineage. Biochem J 361: 621-627.

9) Klemm DJ, Leitner JW, Watson P, Nesterova A, Reusch JE, Goalstone ML, Draznin B. 2001. Insulin-induced adipocyte differentiation. Activation of CREB rescues adipogenesis from the arrest caused by inhibition of prenylation. J Biol Chem 276: 28430-28435.

10) Prusty D, Park BH, Davis KE, Farmer SR. 2002. Activa- tion of MEK/ERK signaling promotes adipogenesis by enhancing peroxisome proliferator-activated receptor gamma (PPARgamma) and C/EBPalpha gene expression during the differentiation of 3T3-L1 preadipocytes. $J$ Biol Chem 277: 46226-46232.

11) Green H, Kehinde O. 1974. Sublines of mouse 3T3-L1 cells that accumulate lipid. Cell 1: 113-116.

12) Green H, Meuth M. 1974. An established pre-adipose cell line and its differentiation in culture. Cell 3: 127133.

13) Green H, Kehinde O. 1975. An established preadipose cell line and its differentiation in culture II. Factors affecting the adipose conversion. Cell 5: 19-27.

14) Hypponen E, Power C. 2006. Vitamin D status and glucose homeostasis in the 1958 British birth cohort: the role of obesity. Diabetes Care 29: 2244-2246.

15) Hahn S, Haselhorst U, Tan S, Quadbeck B, Schmidt M, Roesler S, Kimmig R, Mann K, Janssen OE. 2006. Low serum 25-hydroxyvitamin D concentrations are associated with insulin resistance and obesity in women with polycystic ovary syndrome. Exp Clin Endocrinol Diabetes 114: $577-583$.

16) Florez H, Martinez R, Chacra W, Strickman-Stein N, Levis S. 2007. Outdoor exercise reduces the risk of hypovitaminosis D in the obese. J Steroid Biochem Mol Biol 103: 679-681.

17) Sato M, Hiragun A. 1988. Demonstration of 1 alpha, 25-dihydroxyvitamin $\mathrm{D}_{3}$ receptor-like molecule in ST13 and 3T3 L1 preadipocytes and its inhibitory effects on preadipocytes differentiation. J Cell Physiol 135: 545550.

18) Kawada T, Kamei Y, Sugimoto E. 1996. The possibility of active form of vitamins A and D as suppressors on adipocyte development via ligand-dependent transcriptional regulators. Int J Obes Relat Metab Disord 20: S52S57.

19) Hida Y, Kawada T, Kayahashi S, Ishihara T, Fushiki T. 1998. Counteraction of retinoic acid and 1,25-dihydroxyvitamin $\mathrm{D}_{3}$ on up-regulation of adipocyte differentiation with PPARgamma ligand, an antidiabetic thiazolidinedione, in 3T3-L1 cells. Life Sci 62: PL205-PL211.

20) Kelly KA, Gimble JM. 1998. 1,25-Dihydroxy vitamin $\mathrm{D}_{3}$ inhibits adipocyte differentiation and gene expression in murine bone marrow stromal cell clones and primary cultures. Endocrinology 139: 2622-2628.

21) Sakuma S, Nishioka Y, Imanishi R, Nishikawa K, Sakamoto H, Fujisawa J, Wada K, Kamisaki Y, Fujimoto Y. 2010. cis9, trans11-Conjugated linoleic acid differentiates mouse 3T3-L1 preadipocytes into mature small adipocytes through induction of peroxisome proliferator-activated receptor $\gamma$. J Clin Biochem Nutr 47: 167173.

22) Yoshimoto Y, Norman AW. 1986. Biological activity of vitamin D metabolites and analogs: dose-response study of $45 \mathrm{Ca}$ transport in an isolated chick duodenum perfusion system. J Steroid Biochem 25: 905-909.

23) Tuohimaa P, Golovko O, Kalueff A, Nazarova N, Qiao S, Syvälä H, Talonpoika R, Lou YR. 2005. Calcidiol and prostate cancer. J Steroid Biochem Mol Biol 93: 183190.

24) Alessi MC, Peiretti F, Morange P, Henry M, Nalbone G, Juhan-Vague I. 1997. Production of plasminogen activator inhibitor 1 by human adipose tissue: possible link between visceral fat accumulation and vascular disease. Diabetes 46: 860-867. 
25) Sakamoto T, Woodcock-Mitchell J, Marutsuka K, Mitchell JJ, Sobel BE, Fujii S. 1999. TNF-alpha and insulin, alone and synergistically, induce plasminogen activator inhibitor-1 expression in adipocytes. Am J Physiol 276: C1391-C1397.

26) Blumberg JM, Tzameli I, Astapova I, Lam FS, Flier JS, Hollenberg AN. 2006. Complex role of the vitamin D receptor and its ligand in adipogenesis in 3T3-L1 cells. J Biol Chem 281: 11205-11213.

27) Font de Mora J, Porras A, Ahn N, Santos E. 1997. Mitogen-activated protein kinase activation is not necessary for, but antagonizes, 3T3-L1 adipocytic differentiation. Mol Cell Biol 17: 6068-6075.
28) Kim SW, Muise AM, Lyons PJ, Ro HS. 2001. Regulation of adipogenesis by a transcriptional repressor that modulates MAPK activation. I Biol Chem 276: 1019910206.

29) Hu E, Kim JB, Sarraf P, Spiegelman BM. 1996. Inhibition of adipogenesis through MAP kinase-mediated phosphorylation of PPARgamma. Science 274: 21002103.

30) Adams M, Reginato MJ, Shao D, Lazar MA, Chatterjee VK. 1997. Transcriptional activation by peroxisome proliferator-activated receptor gamma is inhibited by phosphorylation at a consensus mitogen-activated protein kinase site. J Biol Chem 272: 5128-5132. 